\title{
EXTRACELLULAR HYDROLYTIC ENZYMES OF YEASTS ISOLATED FROM FRUIT AND BEET PEELS IN ALGERIA
}

\author{
Fatima-Zohra Kenza Labbani1 ${ }^{1,2,}$, Scheherazad Dakhmouche ${ }^{1,2}$, Leila Bennamoun ${ }^{2,3}$, \\ Amel Ait-Kaki ${ }^{2,4}$, Tahar Nouadri ${ }^{2,3}$

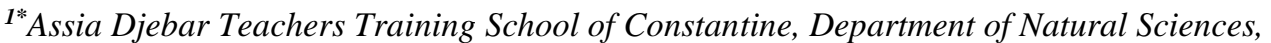 \\ Ville Universitaire Ali Mendjeli, 25000 Constantine, Algeria; \\ ${ }^{2 *}$ Frères Mentouri Constantin 1 University, Faculty of Natural Sciences, Laboratory of Microbiological \\ Engineering and Applications, BP 325, Route de Ain El Bey, 25017 Constantine, Algeria; \\ ${ }^{3}$ Frères Mentouri Constantin 1 University, Faculty of Natural Sciences, Department of Biochemistry \& Cellular \\ and Molecular Biology, BP 325, Route de Ain El Bey, 25017 Constantine, Algeria; \\ ${ }^{4}$ Frères Mentouri Constantin 1 University, The Institute of Nutrition and Food and of Agri-Food Technologies, \\ BP 325, Route de Ain El Bey, 25017 Constantine, Algeria;
}

"Corresponding Author F. Z. K. Labbani, e-mail: labbani.fatimazohra@ensc.dz;

Received October 2021; Accepted November 2021; Published January 2022;

DOI: https://doi.org/10.31407/ijees12.102

\begin{abstract}
Fourty-two yeast strains were isolated from natural sources in Algeria. Based on the sequence analysis of the $26 \mathrm{~S}$ ribosomal RNA D1/D2 domain they were identified to be of 8 species belonging to the genera Aureobasidium, Candida, Clavispora, Hanseniaspora, Pichia, Rhodotorula and Vishniacozyma. All yeast isolates were screened for cellulase, amylase, protease and lipase production. Six strains of Aureobasidium pullulans, Rhodotorula diobovata and Vishniacozyma tephrensis demonstrated ability to produce at least one extracellular enzyme. The enzyme activity index (EAI) for cellulase was noted to be prominent in the isolates of A. pullulans (A1, A3, A5) and $V$. tephrensis A4 as 2.3 and 2.1, respectively. Highest EAI for amylase and protease was also seen in A. pullulans isolate A1 $(\mathrm{EAI}=2.9)$ and isolate A3 $(\mathrm{EAI}=1.9)$, respectively. For lipase, the EAI was superior in $V$. tephrensis A4 $(\mathrm{EAI}=1.5)$ when compared to the isolates of $R$. diobovata $(\mathrm{B} 1, \mathrm{O} 5)(\mathrm{EAI}=1.4)$ and A. pullulans A5 $(\mathrm{EAI}=1.3)$. To the best of our knowledge, this is the first report of cellulase and/or lipase activity in $V$. tephrensis and $R$. diobovata strains associated with apple, orange and beet peels in Algeria. Furthermore, the strain A. pullulans A5 showed enzymatic activities for all the enzymes screened in the current work. Thus, our study can provide further information about the diversity and enzyme production by yeasts and demonstrated the potential for yeast isolated from fruit and beet peels as sources for extracellular hydrolytic enzymes.
\end{abstract}

Keywords: yeast isolation, fruit peels, beet peels, extracellular hydrolytic enzymes, molecular identification. 